\title{
In Vitro Cell Culture Models of Hyperoxaluric States: Calcium Oxalate and Renal Epithelial Cell Interactions
}

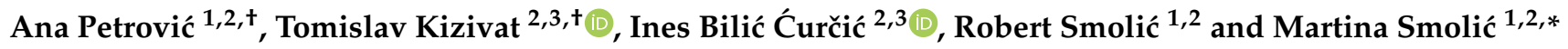 \\ 1 Faculty of Dental Medicine and Health Osijek, University of Osijek, HR-31000 Osijek, Croatia; \\ petrovic.ana.hr@gmail.com (A.P.); rsmolic@mefos.hr (R.S.) \\ 2 Faculty of Medicine Osijek, University of Osijek, HR-31000 Osijek, Croatia; tkizivat@mefos.hr (T.K.); \\ ibcurcic@mefos.hr (I.B.Ć.) \\ 3 Clinical Institute of Nuclear Medicine and Radiation Protection, University Hospital Osijek, \\ HR-31000 Osijek, Croatia \\ * Correspondence: martina.smolic@mefos.hr \\ + Authors contributed equally.
}

check for updates

Citation: Petrović, A.; Kizivat, T. Bilić Ćurčić, I.; Smolić, R.; Smolić, M. In Vitro Cell Culture Models of Hyperoxaluric States: Calcium Oxalate and Renal Epithelial Cell Interactions. Crystals 2021, 11, 735. https://doi.org/10.3390/ cryst11070735

Academic Editors:

Anamarija Stanković,

Martina Medvidović-Kosanović, Branka Njegić Džakula and Jasminka Kontrec

Received: 24 May 2021

Accepted: 21 June 2021

Published: 25 June 2021

Publisher's Note: MDPI stays neutral with regard to jurisdictional claims in published maps and institutional affiliations.

Copyright: (c) 2021 by the authors. Licensee MDPI, Basel, Switzerland. This article is an open access article distributed under the terms and conditions of the Creative Commons Attribution (CC BY) license (https:// creativecommons.org/licenses/by/ $4.0 /)$.

\begin{abstract}
Urolithiasis is a multifactorial disease with a high incidence and high recurrence rate, characterized by formation of solid deposits in the urinary tract. The most common type of these stones are calcium oxalate stones. Calcium oxalate crystals can, in hyperoxaluric states, interact with renal epithelial cells, causing injury to the renal epithelia. Pathogenesis of urolithiasis is widely investigated, but underlying mechanisms are still not completely clarified. In vitro models offer insight into molecular processes which lead to renal stone formation and are significant for evaluation of prophylactic and therapeutic management of patients with urolithiasis. In this review, we summarize recently published data from in vitro studies investigating interactions of calcium oxalate crystals with renal epithelial cell lines, anti-urolithiatic mechanisms, and the results from studies exploring possible therapeutic and prophylactic options for calcium oxalate urolithiasis in cell cultures.
\end{abstract}

Keywords: calcium oxalate; cell culture; urolithiasis; antioxidants; hyperoxaluria

\section{Introduction}

Nephrolithiasis is one of the oldest public health problems described in sources dating back to 4000 B.C. [1,2]. About $12 \%$ of the world population experience kidney stones at some point in their lives [2], and the prevalence of this condition has increased over the past two decades [3], which is probably associated with lifestyle changes regarding physical activity, nutrition, and modern-day stress [4]. Studies have shown that renal stone formation is highly associated with low fluid and high sodium intake, nutrition rich in protein and carbohydrates, increased BMI, and comorbidities such as gout, high blood pressure, and diabetes $[5,6]$.

Calcium oxalate $(\mathrm{CaOx})$ is the most common component found in $80 \%$ of all renal stones with significantly higher prevalence than apatite, uric acid, pure calcium phosphate stones, cystine, and calcium ammonium phosphate (struvite) stones. CaOx can exist in the form of calcium oxalate monohydrate (COM), dihydrate (COD), or as a combination of both [7]. Around $80 \%$ of $\mathrm{CaOx}$ stones contain variable amounts of $\mathrm{Ca}$ phosphate as apatite. Mechanisms of renal stone formation include complex biochemical processes which are still not completely understood. Hyperoxaluria, supersaturation of urine, crystal nucleation, growth, aggregation, crystal-cell interaction, cytotoxicity, cell injury, and apoptosis are believed to be underlying mechanisms for stone formation and clinical manifestations of kidney stone disease [8-10]. In view of their high recurrence rate, limited options for prevention, and associated risks for chronic kidney disease, renal cancer and failure, metabolic disorders, and cardiovascular disease [11], there is a need for further investigation of kidney 
stone disease pathophysiology, diagnosis, and treatment options. Cell culture studies offer valuable data for understanding the complex biochemical mechanisms in nephrolithiasis and detecting potential therapeutic and prophylactic methods.

\section{Interactions of Calcium Oxalate on Renal Epithelial Cells}

\subsection{Cytotoxicity}

Calcium oxalate crystallization, crystal-cell interaction, and subsequent renal injury is a cascade of processes depending on many intrarenal and extrarenal factors. The morphology of the crystals has great influence on internalization, cytotoxicity, and, subsequently, renal injury. To explore the influence of the size, crystal phase, and morphology on cytotoxicity, Sun et al. conducted a study on COM-treated Vero cells (African green monkey renal epithelial cells) using various crystals. Examining the cell viability, membrane damage, reactive oxygen species (ROS), mitochondrial membrane potential, and cell apoptosis/necrosis, toxicity was observed in the following order: COM-1 $\mu \mathrm{m}>\mathrm{COM}-200$ $\mathrm{nm}>\mathrm{COM}-50 \mathrm{~nm}>\mathrm{COM}-3 \mu \mathrm{m}>\mathrm{COM}-10 \mu \mathrm{m}$, since the morphology and surface area of $\mathrm{CaOx}$ crystals change with their size [12]. When exposed to different shaped COD crystals, human kidney proximal tubular epithelial (HK-2) cells showed that crystals with large faces (elongated-bipyramid) and sharp edges (cross-shaped) exhibited the highest cytotoxicity. COM and COD exposure caused membrane integrity disruption, elevated intracellular reactive oxygen, decreased mitochondrial membrane potential, and ultimately cell apoptosis and necrosis, suggesting a cellular and molecular mechanism of cell injury induced by $\mathrm{CaOx}$ crystals [13]. Liu et. al. explored the role of autophagy in HK-2 cells exposed to $\mathrm{CaOx}$ crystals and found an increased number of GFP-LC3 dots and autophagic vacuoles which degraded damaged organelles, concluding that $\mathrm{CaOx}$ crystals induced autophagy via activation of ROS pathway, although the mechanism of this activation is still not clarified [14].

\subsection{Adhesion and Internalization of $\mathrm{CaOx}$ Crystals}

The adhesion and internalization of crystals play a vital role in stone formation and cell damage. Smaller (nano-sized) crystals reflect higher adherence to Vero cells than larger (micron-sized) crystals. Internalization pathways also change with the size of the crystals. Nano-sized crystals are mainly internalized through clathrin-mediated endocytosis, transferred to lysosomes, and show high lysosomal damage leading to cell death, while micron-sized crystals uptake happens mainly through macropinocytosis and shows mild cell damage [15]. At lower exposures, Lieske et. al. found that internalized $\mathrm{CaOx}$ crystals retained in BSC-1 kidney cells for several weeks without apparent toxicity and appeared to dissolve within lysosomes after 5-7 weeks [16]. Grover et al. found that intracrystalline urinary proteins facilitated the degradation and dissolution of $\mathrm{CaOx}$ crystals in MDCK cells [17]. They proposed that the proteins were degraded by lysosomal proteases, exposing more crystal surface to mineral dissolution in the highly acidic lysosomal interior. Manissorn, Fong-Ngern, Peerapen, and Thongboonkerd explored the influence of urine $\mathrm{pH}$ on $\mathrm{CaOx}$ crystallization, cell adhesion, and internalization, revealing COM crystallized with the greatest size, number, and total mass at $\mathrm{pH} 4.0$ and least crystallized at $\mathrm{pH}$ 8.0, while COD crystallization and $\mathrm{pH}$ correlation were the opposite of COM. Adhesion was greatest at the most acidic $\mathrm{pH}$ and least at the most basic $\mathrm{pH}$, while internalization was maximal at the neutral $\mathrm{pH}$ [18]. Insight into these mechanisms offers new information for finding potential crystal-uptake inhibitors that could decrease cell injury in nephrolithiasis.

\subsection{Epithelial-to-Mesenchymal Transition (EMT)}

Epithelial-to-mesenchymal transition (EMT), which plays an important role in processes such as inflammation, cancer, and fibrosis, is phenotypical transformation of epithelial cells in which cell-cell adhesion, morphological characteristics and polarity weaken while invasiveness and cell migration increases. This process could also be induced by oxalate crystals, most likely by activation of TGF- $\beta 1$ and the Notch/Snail pathway $[19,20]$. 
A key profibrotic cytokine in this process is TGF- $\beta 1$, produced mainly by macrophages and significantly stimulated by $\mathrm{CaOx}$. The HK-2 cell line exposed to calcium oxalate presents increased TGF- $\beta 1$ production, decreased expression of epithelial and increased mesenchymal markers, and significant mesenchymal changes, migration, and invasiveness [21]. Similar results were observed in vitro in the CaOx-exposed Madin-Darby canine kidney (MDCK) cell line, supporting the evidence for EMT in kidney stone disease [20].

\subsection{Inflammatory/Immune Response}

Renal cell injury is also mediated through strong inflammatory immune response. Significant immune response to calcium oxalate crystals is also mediated by monocytes. The human monocytic cell line THP-1 shows high activation by calcium oxalate, increased production of inflammatory cytokines, and promotion of M1 macrophage development [22]. The effects of activated macrophages on $\mathrm{CaOx}$ induced cell damage have been extensively explored [23]. Macrophages can, in different microenvironments, be activated as M1 and $\mathrm{M} 2$, the first with a proinflammatory effect, inducing damage, and the second one with an anti-inflammatory effect, inducing tissue repair and tumor growth [24]. When HK-2 cells were exposed to M2 activated macrophages and CaOx crystals, inflammatory reaction, epithelial cell damage, apoptosis, and oxidative damage were decreased. The proposed mechanism was inhibition of the NADPH oxidase/ROS/P38 MAPK pathway and activation of the PI3K/Akt pathway [23]. In vitro CaOx-exposed macrophages, derived from peripheral blood mononuclear cells (PBMC) isolated from human buffy coat samples, presented the ability to surround $\mathrm{CaOx}$ crystals and digest them through clathrin-mediated endocytosis and phagocytosis. Calcium oxalate also triggered an inflammatory cascade produced by macrophages, including chemokines CCL2, CCL3, interleukin-1 receptor antagonist (IL-1ra), complement component C5/C5a, and IL-8 [25].

\subsection{Oxidative Stress (ROS)}

High concentrations of oxalate in urine can cause renal tubular epithelial cell damage and considerably contribute to the deposition and growth of $\mathrm{CaOx}$ crystals [26]. Increased $\mathrm{CaOx}$ crystal adhesion and aggregation on epithelial cells is associated with high production of ROS, resulting in lipid peroxidation of the membrane and damage to the mitochondria, endoplasmic reticulum, and other cell components through oxidative stress [27,28]. Transforming growth factor- $\beta 1$ (TGF- $\beta 1$ ) plays a significant role in multiple kidney diseases including glomerulonephritis, renal interstitial fibrosis, and nephrolithiasis [29]. It is possible that oxalate-induced production of ROS is the result of TGF- $\beta 1$ activation [30].

\subsection{DNA Expression and Transcription}

There are several groups of proteins in urine, blood, and kidney tissue that modulate cell-crystal interaction and crystal formation. In a review paper published in 2019, Thongboonkerd summarized and provided valuable data obtained from recent proteomic approach studies [31], offering a systematic review of main findings regarding calcium oxalate crystal receptors on the apical surface of renal tubular cells, effects of $\mathrm{CaOx}$ crystals on cellular proteome of renal tubular cells, cellular proteome of monocytes and macrophages, and secretome and exosomal proteome [32-41]. In their recently published study, Khamchun et al. identified the dual role of fibronectin in pathogenesis of kidney stones, showing its inhibiting function for COM crystallization, growth, and adhesion to renal cells, and conversely, its promotion of COM aggregation and invasion through the extracellular matrix [42]. Calcium oxalate exposure also resulted in gene expression and transcriptome changes. Exposing the renal, proximal, tubular, epithelial cell line HK-2 to COM resulted in miR-21 expression upregulation and proliferation inhibition, promoted apoptosis, and caused the accumulation of intracellular lipid droplets in cells. Screening for mRNA target prediction identified peroxisome proliferator activated receptor alpha (PPARA) downregulation, an important gene in fatty acid oxidation. This study suggested that miR-21 could potentially be a biomarker for nephrolithiasis and therapeutic target [43]. In a similar 
study, miR-155 and its role in CaOx-induced renal cell injury was explored by establishing a CaOx-induced HK-2 model that presented cell injury in a dose-dependent manner, increased apoptosis, increased levels of IL1 $\beta$, IL-6, and TNF-scripta, and elevated expression of miR-155 in treated cells. Further analysis indicated that miR-155 had a significant role in autophagy through the PI3K/Akt/mTOR pathway. It seems that the miR-155 is highly expressed in nephrolithiasis, which induces autophagic activity and promotes cell injury through the PI3K/Akt/mTOR signaling pathway [44].

\section{Anti-Urolithiatic Mechanisms and Therapeutic/Prophylactic Options}

Calcium oxalate is a highly toxic final product which cannot be further metabolized and is a major component of kidney stones. The exact pathophysiological mechanism of crystal formation and adhesion to the epithelial cell is still not clarified and is modulated by a myriad of factors, including changes in calcium concentrations, oxalate content, alteration in expression of macromolecules involved in modulation of crystallization, remodeling of extracellular matrix, epithelial-to-mesenchymal transition, and others [45]. However, interaction between oxalate ions and renal cells was identified as a precursor of cellular injury and a starting point of stone formation. Since oxalate ions produce reactive oxygen species (ROS), increase in oxidative stress, prevention of ROS generation, and increase in the antioxidant capacity of the cell can prevent cellular injury [46]. It is important to note that the work of Evan's group indicates that the vast majority of the common idiopathic $\mathrm{CaOx}$ stones form on Randall's plaques on the thin limbs of the loop of Henle outside of collecting ducts, and that intratubular formation is rare $[47,48]$.

\subsection{PPAR- $\gamma$ Agonists}

Peroxisome proliferator-activated receptor- $\gamma$ (PPAR- $\gamma)$, a nuclear hormone receptor, has a significant role in cellular proliferation, morphogenesis, inflammation, and in the preservation off cell metabolic homeostasis [28]. It is highly expressed in renal tissues including inner medullary collecting ducts, distal tubules, and the ascending limb of Henle's loop [49], where it modulates gene expression through peroxisome proliferator response element (PPRE) sites and influences transcription of target genes [50]. PPAR- $\gamma$ agonists could prevent crystal formation and cause a decrease of oxidative stress caused by oxalate, in part by inhibition of TGF- $\beta 1$ signaling transduction $[20,27,51]$. In addition, PPAR- $\gamma$ agonists also bind to hepatocyte growth factor (HGF) and lead to increased HGF gene expression. Considering that the HGF/c-Met signaling pathway is a key regulator of oxidative stress in cells, its activation through PPAR $-\gamma$ agonists could improve cellular antioxidant capacity [51].

A recent study by Liu YD et al. showed that rosiglitazone, a PPAR- $\gamma$ agonist, inhibited TGF- $\beta 1$ and enhanced the HGF/c-Met pathway in tubular cells exposed to oxalate and exhibited antioxidant and nephroprotective effects [27]. Partial PPAR- $\gamma$ agonist and highly sensitive angiotensin II type 1 receptor blocker (ARB) telmisartan could also inhibit oxalate and calcium oxalate induced epithelial-mesenchymal transition (EMT) by exerting antioxidative effects via the PPAR- $\gamma$-AKT/STAT3/p38 MAPK-Snail signaling pathway [52].

\subsection{Anti-Inflammatory Drugs}

Another important aspect of prevention of kidney stone formation is a decrease in inflammatory response. The importance of reducing the inflammatory response was also shown through effects of atorvastatin on HK-2 cells exposed to CaOx, exhibiting antioxidative effects by inhibiting activation of TLR4/NF-KB and NLRP3 inflammasome pathways and release of inflammatory mediators (including IL-1 $\beta$, IL-18, IL-6, and TNF- $\alpha$ ) [53].

\subsection{Antioxidants/Plant Extracts}

Recently, extensive research has explored the effectiveness of generic antioxidants and plant extracts on the alleviation of $\mathrm{CaOx}$ crystal damage to epithelial cells, among others 
L-arginine [46], vitamin E [46], theaflavin [54], taurine [55], corn silk polysaccharides [56], polysaccharides from green seaweed [57], aspidopterys obcordata [58], terminalia arjuna [59], etc. Studies showed that the effects of these antioxidants were beneficial for alleviating oxidative stress on epithelial cells by reducing markers of oxidative damage and increasing cell viability. For some, the underlying mechanisms of these effects have been established. Theaflavin effects are mediated via the miR-128-3p/SIRT1 axis [54], taurine inhibition of ROS-dependent autophagy is facilitated by activating the Akt/mTOR signaling pathway [55], while TGAME (plant metabolite 3,4,5-tri-O-galloylquinic acid methyl ester) decreases annexin A1 cell surface expression [60]. Further research is needed in order to determine mechanisms of action for other antioxidants and plant extracts, and whether there are other pathways present apart from free radical scavenging.

\section{Conclusions}

The incidence and prevalence of urolithiasis is constantly increasing, thus presenting an important public health issue, but there is still much to be learned about the stone formation, initial crystallization, and interaction of crystals and epithelial cells. Recently, significant progress has been made in understanding the pathophysiology of urinary stone formation. Studies showed the different effects of crystal size and shape on epithelial cells, also giving insight into the importance of oxidative damage and inflammatory response that caused apoptosis of the epithelial cells. Research that has gone deeper on the protein and miRNA level has provided more details of the intricate interaction of pro-stone and anti-stone formation factors. It is the authors' opinion that, as a future prospect, it will be important to keep exploring proteome and transcriptome changes caused by $\mathrm{CaO}$ crystals, and to carry over this exploration to in vivo studies on animal models, enabling us to consider the kidney as a whole, and not only its epithelial surface. However, most of these studies have used $\mathrm{CaOx}$ crystals that have no protein in them, so called "naked" crystals, yet in an in vivo milieu, kidney stones contain proteins, possibly altering the effects of crystal-cell interaction. Moreover, another issue exists considering the in vitro models of urolithiasis. Most, if not all, cell models that have been exposed to CaOx crystals do not usually, in humans, come in contact with CaOx crystals, except in cases of hyperoxaluria or in case of ethylene glycol poisoning, because the crystals usually become attached to epithelial cells on Randall's plaques located in the loop of Henle [7,47,48], although some cell models used do represent collecting ducts [46,61] located after Randall's plaque. The question that emerges is whether these models, which most authors link to urolithiasis, are clinically relevant to the most common idiopathic urolithiasis or only to states of hyperoxaluria.

Regarding therapy and/or prevention of urolithiasis, the latest research has provided insight into inflammasome and gene activation pathways of different therapeutic options, revealing that it is not only the free radical scavenging activity of antioxidants that is important in the prevention of epithelial damage. Important pathways linking PPAR- $\gamma$ with effector proteins were also shown to have a significant role, and PPAR- $\gamma$ agonists have shown good results in in vitro models. Considering plant extracts with antioxidative properties, there are still a few puzzles left to be solved. There is a lack of understanding about the bioactive component of plant extracts, and also their safety. What is the quality and quantity of the extracts, and what is the efficacy of the extraction methods? Moreover, some of the plant extracts have been shown to be damaging to the kidneys [62]. Future research should address these issues in order to understand if these therapeutics even reach the kidney in an in vivo model.

Author Contributions: Conceptualization, M.S. and R.S.; writing—original draft preparation, A.P. and T.K.; writing-review and editing, I.B.Ć. and T.K.; supervision, I.B.C. and R.S.; funding acquisition, M.S. All authors have read and agreed to the published version of the manuscript. 
Funding: This research was funded by a grant from Croatian Ministry of Science and Education dedicated to multi-year institutional funding of scientific activity at the J.J. Strossmayer University of Osijek, Osijek, Croatia, grant number IP-13-2020-MEFOS to Martina Smolić.

Institutional Review Board Statement: Not applicable.

Informed Consent Statement: Not applicable.

Conflicts of Interest: The authors declare no conflict of interest.

\section{References}

1. López, M.; Hoppe, B. History, epidemiology and regional diversities of urolithiasis. Pediatr. Nephrol. 2010, 25, 49-59. [CrossRef]

2. Alelign, T.; Petros, B. Kidney Stone Disease: An Update on Current Concepts. Adv. Urol. 2018, 2018, 3068365. [CrossRef] [PubMed]

3. Scales, C.D.; Smith, A.C.; Hanley, J.M.; Saigal, C.S.; Urologic Diseases in America Project. Prevalence of kidney stones in the United States. Eur. Urol. 2012, 62, 160-165. [CrossRef]

4. Moe, O.W. Kidney stones: Pathophysiology and medical management. Lancet 2006, 367, 333-344. [CrossRef]

5. Aune, D.; Mahamat-Saleh, Y.; Norat, T.; Riboli, E. Body fatness, diabetes, physical activity and risk of kidney stones: A systematic review and meta-analysis of cohort studies. Eur. J. Epidemiol. 2018, 33, 1033-1047. [CrossRef]

6. Fontenelle, L.F.; Sarti, T.D. Kidney Stones: Treatment and Prevention. Am. Fam. Physician 2019, 99, 490-496. [PubMed]

7. Evan, A.P. Physiopathology and etiology of stone formation in the kidney and the urinary tract. Pediatr. Nephrol. 2010, $25,831-841$. [CrossRef] [PubMed]

8. Khan, S.R.; Pearle, M.S.; Robertson, W.G.; Gambaro, G.; Canales, B.K.; Doizi, S.; Traxer, O.; Tiselius, H.G. Kidney stones. Nat. Rev. Dis. Primers. 2016, 2, 16008. [CrossRef]

9. Aggarwal, K.P.; Narula, S.; Kakkar, M.; Tandon, C. Nephrolithiasis: Molecular mechanism of renal stone formation and the critical role played by modulators. Biomed. Res. Int. 2013, 2013, 292953. [CrossRef]

10. Coe, F.L.; Evan, A.; Worcester, E. Kidney stone disease. J. Clin. Investig. 2005, 115, 2598-2608. [CrossRef]

11. Courbebaisse, M.; Prot-Bertoye, C.; Bertocchio, J.P.; Baron, S.; Maruani, G.; Briand, S.; Daudon, M.; Houillier, P. Nephrolithiasis of adult: From mechanisms to preventive medical treatment. Rev. Med. Interne 2017, 38, 44-52. [CrossRef] [PubMed]

12. Sun, X.Y.; Ouyang, J.M.; Gan, Q.Z.; Liu, A.J. Renal Epithelial Cell Injury Induced by Calcium Oxalate Monohydrate Depends on their Structural Features: Size, Surface, and Crystalline Structure. J. Biomed. Nanotechnol. 2016, 12, $2001-2014$. [CrossRef] [PubMed]

13. Sun, X.Y.; Ouyang, J.M.; Yu, K. Shape-dependent cellular toxicity on renal epithelial cells and stone risk of calcium oxalate dihydrate crystals. Sci. Rep. 2017, 7, 7250. [CrossRef]

14. Liu, Y.; Li, D.; He, Z.; Liu, Q.; Wu, J.; Guan, X.; Tao, Z.; Deng, Y. Inhibition of autophagy-attenuated calcium oxalate crystal-induced renal tubular epithelial cell injury. Oncotarget 2018, 9, 4571-4582. [CrossRef]

15. Sun, X.Y.; Gan, Q.Z.; Ouyang, J.M. Size-dependent cellular uptake mechanism and cytotoxicity toward calcium oxalate on Vero cells. Sci. Rep. 2017, 7, 41949. [CrossRef] [PubMed]

16. Lieske, J.C.; Norris, R.; Swift, H.; Toback, F.G. Adhesion, internalization and metabolism of calcium oxalate monohydrate crystals by renal epithelial cells. Kidney Int. 1997, 52, 1291-1301. [CrossRef]

17. Grover, P.K.; Thurgood, L.A.; Fleming, D.E.; van Bronswijk, W.; Wang, T.; Ryall, R.L. Intracrystalline urinary proteins facilitate degradation and dissolution of calcium oxalate crystals in cultured renal cells. Am. J. Physiol. Ren. Physiol. 2008, 294, F355-F361. [CrossRef] [PubMed]

18. Manissorn, J.; Fong-Ngern, K.; Peerapen, P.; Thongboonkerd, V. Systematic evaluation for effects of urine $\mathrm{pH}$ on calcium oxalate crystallization, crystal-cell adhesion and internalization into renal tubular cells. Sci. Rep. 2017, 7, 1798. [CrossRef] [PubMed]

19. Tian, H.; Yang, J.; Xie, Z.; Liu, J. Gliquidone Alleviates Diabetic Nephropathy by Inhibiting Notch/Snail Signaling Pathway. Cell Physiol. Biochem. 2018, 51, 2085-2097. [CrossRef]

20. Li, S.; Lan, Y.; Wu, W.; Duan, X.; Kong, Z.; Zeng, G. Peroxisome proliferator-activated receptor $\gamma$ modulates renal crystal retention associated with high oxalate concentration by regulating tubular epithelial cellular transdifferentiation. J. Cell Physiol. 2019, 234, 2837-2850. [CrossRef]

21. Convento, M.B.; Pessoa, E.A.; Cruz, E.; da Glória, M.A.; Schor, N.; Borges, F.T. Calcium oxalate crystals and oxalate induce an epithelial-to-mesenchymal transition in the proximal tubular epithelial cells: Contribution to oxalate kidney injury. Sci. Rep. 2017, 7, 45740. [CrossRef] [PubMed]

22. Dominguez-Gutierrez, P.R.; Kusmartsev, S.; Canales, B.K.; Khan, S.R. Calcium Oxalate Differentiates Human Monocytes Into Inflammatory M1 Macrophages. Front. Immunol. 2018, 9, 1863. [CrossRef] [PubMed]

23. Liu, Q.; Liu, Y.; Guan, X.; Wu, J.; He, Z.; Kang, J.; Tao, Z.; Deng, Y. Effect of M2 Macrophages on Injury and Apoptosis of Renal Tubular Epithelial Cells Induced by Calcium Oxalate Crystals. Kidney Blood Press. Res. 2019, 44, 777-791. [CrossRef]

24. Stöger, J.L.; Gijbels, M.J.; van der Velden, S.; Manca, M.; van der Loos, C.M.; Biessen, E.A.; Daemen, M.J.; Lutgens, E.; de Winther, M.P. Distribution of macrophage polarization markers in human atherosclerosis. Atherosclerosis 2012, 225, 461-468. [CrossRef]

25. Kusmartsev, S.; Dominguez-Gutierrez, P.R.; Canales, B.K.; Bird, V.G.; Vieweg, J.; Khan, S.R. Calcium Oxalate Stone Fragment and Crystal Phagocytosis by Human Macrophages. J. Urol. 2016, 195, 1143-1151. [CrossRef] 
26. Yu, S.L.; Gan, X.G.; Huang, J.M.; Cao, Y.; Wang, Y.Q.; Pan, S.H.; Ma, L.Y.; Teng, Y.Q.; An, R.H. Oxalate impairs aminophospholipid translocase activity in renal epithelial cells via oxidative stress: Implications for calcium oxalate urolithiasis. J. Urol. 2011, 186, 1114-1120. [CrossRef]

27. Liu, Y.D.; Yu, S.L.; Wang, R.; Liu, J.N.; Jin, Y.S.; Li, Y.F.; An, R.H. Rosiglitazone Suppresses Calcium Oxalate Crystal Binding and Oxalate-Induced Oxidative Stress in Renal Epithelial Cells by Promoting PPAR-. Oxid. Med. Cell. Longev. 2019, 2019, 4826525. [CrossRef]

28. Chen, Y.; Feng, X.; Hu, X.; Sha, J.; Li, B.; Zhang, H.; Fan, H. Dexmedetomidine Ameliorates Acute Stress-Induced Kidney Injury by Attenuating Oxidative Stress and Apoptosis through Inhibition of the ROS/JNK Signaling Pathway. Oxid. Med. Cell. Longev. 2018, 2018, 4035310. [CrossRef] [PubMed]

29. Lan, H.Y.; Chung, A.C. TGF- $\beta$ /Smad signaling in kidney disease. Semin. Nephrol. 2012, 32, 236-243. [CrossRef] [PubMed]

30. Rashed, T.; Menon, M.; Thamilselvan, S. Molecular mechanism of oxalate-induced free radical production and glutathione redox imbalance in renal epithelial cells: Effect of antioxidants. Am. J. Nephrol. 2004, 24, 557-568. [CrossRef]

31. Thongboonkerd, V. Proteomics of Crystal-Cell Interactions: A Model for Kidney Stone Research. Cells 2019, 8, 1076. [CrossRef]

32. Singhto, N.; Kanlaya, R.; Nilnumkhum, A.; Thongboonkerd, V. Roles of Macrophage Exosomes in Immune Response to Calcium Oxalate Monohydrate Crystals. Front. Immunol. 2018, 9, 316. [CrossRef] [PubMed]

33. Peerapen, P.; Chaiyarit, S.; Thongboonkerd, V. Protein Network Analysis and Functional Studies of Calcium Oxalate CrystalInduced Cytotoxicity in Renal Tubular Epithelial Cells. Proteomics 2018, 18, e1800008. [CrossRef]

34. Sintiprungrat, K.; Singhto, N.; Thongboonkerd, V. Characterization of calcium oxalate crystal-induced changes in the secretome of U937 human monocytes. Mol. Biosyst. 2016, 12, 879-889. [CrossRef]

35. Chaiyarit, S.; Singhto, N.; Thongboonkerd, V. Calcium oxalate monohydrate crystals internalized into renal tubular cells are degraded and dissolved by endolysosomes. Chem. Biol. Interact. 2016, 246, 30-35. [CrossRef]

36. Vinaiphat, A.; Thongboonkerd, V. Characterizations of PMCA2-interacting complex and its role as a calcium oxalate crystalbinding protein. Cell Mol. Life Sci. 2018, 75, 1461-1482. [CrossRef]

37. Singhto, N.; Thongboonkerd, V. Exosomes derived from calcium oxalate-exposed macrophages enhance IL-8 production from renal cells, neutrophil migration and crystal invasion through extracellular matrix. J. Proteom. 2018, 185, 64-76. [CrossRef]

38. Fong-Ngern, K.; Sueksakit, K.; Thongboonkerd, V. Surface heat shock protein 90 serves as a potential receptor for calcium oxalate crystal on apical membrane of renal tubular epithelial cells. J. Biol. Inorg. Chem. 2016, 21, 463-474. [CrossRef]

39. Manissorn, J.; Singhto, N.; Thongboonkerd, V. Characterizations of HSP90-Interacting Complex in Renal Cells Using Tandem Affinity Purification and Its Potential Role in Kidney Stone Formation. Proteomics 2018, 18, e1800004. [CrossRef] [PubMed]

40. Manissorn, J.; Khamchun, S.; Vinaiphat, A.; Thongboonkerd, V. Alpha-tubulin enhanced renal tubular cell proliferation and tissue repair but reduced cell death and cell-crystal adhesion. Sci. Rep. 2016, 6, 28808. [CrossRef]

41. Fong-Ngern, K.; Thongboonkerd, V. Alpha-enolase on apical surface of renal tubular epithelial cells serves as a calcium oxalate crystal receptor. Sci. Rep. 2016, 6, 36103. [CrossRef]

42. Khamchun, S.; Sueksakit, K.; Chaiyarit, S.; Thongboonkerd, V. Modulatory effects of fibronectin on calcium oxalate crystallization, growth, aggregation, adhesion on renal tubular cells, and invasion through extracellular matrix. J. Biol. Inorg. Chem. 2019, 24, 235-246. [CrossRef]

43. Su, B.; Han, H.; Ji, C.; Hu, W.; Yao, J.; Yang, J.; Fan, Y.; Li, J. MiR-21 promotes calcium oxalate-induced renal tubular cell injury by targeting PPARA. Am. J. Physiol. Ren. Physiol. 2020, 319, F202-F214. [CrossRef]

44. Chen, X.; Zhang, X.B.; Li, D.J.; Qi, G.N.; Dai, Y.Q.; Gu, J.; Chen, M.Q.; Hu, S.; Liu, Z.Y.; Yang, Z.M. miR-155 facilitates calcium oxalate crystal-induced HK-2 cell injury via targeting PI3K associated autophagy. Exp. Mol. Pathol. 2020, 115, 104450. [CrossRef]

45. Albert, A.; Paul, E.; Rajakumar, S.; Saso, L. Oxidative stress and endoplasmic stress in calcium oxalate stone disease: The chicken or the egg? Free Radic. Res. 2020, 54, 244-253. [CrossRef]

46. Kizivat, T.; Smolic, M.; Maric, I.; Levak, M.T.; Smolic, R.; Curcic, I.B.; Kuna, L.; Mihaljevic, I.; Vcev, A.; Tucak-Zoric, S. Antioxidant Pre-Treatment Reduces the Toxic Effects of Oxalate on Renal Epithelial Cells in a Cell Culture Model of Urolithiasis. Int. J. Environ. Res. Public Health 2017, 14, 109. [CrossRef]

47. Evan, A.P.; Coe, F.L.; Lingeman, J.; Bledsoe, S.; Worcester, E.M. Randall's plaque in stone formers originates in ascending thin limbs. Am. J. Physiol. Ren. Physiol. 2018, 315, F1236-F1242. [CrossRef] [PubMed]

48. Evan, A.P.; Worcester, E.M.; Coe, F.L.; Williams, J., Jr.; Lingeman, J.E. Mechanisms of human kidney stone formation. Urolithiasis 2015, 43, 19-32. [CrossRef] [PubMed]

49. Yang, T.; Soodvilai, S. Renal and vascular mechanisms of thiazolidinedione-induced fluid retention. PPAR Res. 2008, $2008,943614$. [CrossRef] [PubMed]

50. Sugawara, A.; Uruno, A.; Kudo, M.; Matsuda, K.; Yang, C.W.; Ito, S. Effects of PPAR $\gamma$ on hypertension, atherosclerosis, and chronic kidney disease. Endocr. J. 2010, 57, 847-852. [CrossRef]

51. Lee, K.H.; Kim, J.R. Reactive oxygen species regulate the generation of urokinase plasminogen activator in human hepatoma cells via MAPK pathways after treatment with hepatocyte growth factor. Exp. Mol. Med. 2009, 41, 180-188. [CrossRef] [PubMed]

52. Liu, Y.; Chen, S.; Liu, J.; Jin, Y.; Yu, S.; An, R. Telmisartan inhibits oxalate and calcium oxalate crystal-induced epithelialmesenchymal transformation via PPAR- $\gamma$-AKT/STAT3/p38 MAPK-Snail pathway. Life Sci. 2020, 241, 117108. [CrossRef] 
53. Sun, Y.; Liu, Y.; Guan, X.; Kang, J.; Wang, X.; Liu, Q.; Li, D.; Xu, H.; Tao, Z.; Deng, Y. Atorvastatin inhibits renal inflammatory response induced by calcium oxalate crystals via inhibiting the activation of TLR4/NF- $K B$ and NLRP3 inflammasome. IUBMB Life 2020, 72, 1065-1074. [CrossRef]

54. Ye, T.; Yang, X.; Liu, H.; Lv, P.; Lu, H.; Jiang, K.; Peng, E.; Ye, Z.; Chen, Z.; Tang, K. Theaflavin protects against oxalate calcium-induced kidney oxidative stress injury via upregulation of SIRT1. Int. J. Biol. Sci. 2021, 17, 1050-1060. [CrossRef]

55. Sun, Y.; Dai, S.; Tao, J.; Li, Y.; He, Z.; Liu, Q.; Zhao, J.; Deng, Y.; Kang, J.; Zhang, X.; et al. Taurine suppresses ROS-dependent autophagy via activating Akt/mTOR signaling pathway in calcium oxalate crystals-induced renal tubular epithelial cell injury. Aging (Albany NY) 2020, 12, 17353-17366. [CrossRef]

56. Chen, J.Y.; Sun, X.Y.; Ouyang, J.M. Modulation of Calcium Oxalate Crystal Growth and Protection from Oxidatively Damaged Renal Epithelial Cells of Corn Silk Polysaccharides with Different Molecular Weights. Oxid. Med. Cell. Longev. 2020, 2020, 6982948. [CrossRef]

57. Gomes, D.L.; Melo, K.R.T.; Queiroz, M.F.; Batista, L.A.N.C.; Santos, P.C.; Costa, M.S.S.P.; Almeida-Lima, J.; Camara, R.B.G.; Costa, L.S.; Rocha, H.A.O. In Vitro Studies Reveal Antiurolithic Effect of Antioxidant Sulfated Polysaccharides from the Green Seaweed. Mar. Drugs 2019, 17, 326. [CrossRef]

58. Li, Y.; Ma, G.; Lv, Y.; Su, J.; Li, G.; Chen, X. Efficacy of Obcordata A from. Molecules 2019, 24, 1957. [CrossRef]

59. Mittal, A.; Tandon, S.; Singla, S.K.; Tandon, C. Cytoprotective and anti-apoptotic role of Terminalia arjuna on oxalate injured renal epithelial cells. Cytotechnology 2017, 69, 349-358. [CrossRef]

60. Abd El-Salam, M.; Bastos, J.K.; Han, J.J.; Previdi, D.; Coelho, E.B.; Donate, P.M.; Romero, M.F.; Lieske, J. The Synthesized Plant Metabolite 3,4,5-Tri-O-Galloylquinic Acid Methyl Ester Inhibits Calcium Oxalate Crystal Growth in a Drosophila Model, Downregulates Renal Cell Surface Annexin A1 Expression, and Decreases Crystal Adhesion to Cells. J. Med. Chem. 2018, 61, 1609-1621. [CrossRef]

61. Verkoelen, C.F.; van der Boom, B.G.; Kok, D.J.; Houtsmuller, A.B.; Visser, P.; Schröder, F.H.; Romijn, J.C. Cell type-specific acquired protection from crystal adherence by renal tubule cells in culture. Kidney Int. 1999, 55, 1426-1433. [CrossRef] [PubMed]

62. Brown, A.C. Kidney toxicity related to herbs and dietary supplements: Online table of case reports. Part 3 of 5 series. Food Chem. Toxicol. 2017, 107, 502-519. [CrossRef] [PubMed] 